\title{
Linkage between Flexibility and SMEs Performance: Does Improvisation Matter?
}

\author{
Darwina Arshad, Nazlina Zakaria, Kadzrina Abdul-Kadir and Norzieiriani Ahmad \\ School of Business Management, College of Business, Universiti Utara Malaysia, Malaysia
}

\begin{abstract}
Small Medium Enterprises (SMEs) has become significant in today's economic growth. To gain and sustain the SMEs performance, one of the ways the organization should do is to be flexible and improvise in its business activities. The link between flexibility, improvisation and SMEs performance is still vague, thus this paper aims to investigate the effect of improvisation as a mediator between organizational flexibility and SMEs performance. Three hypotheses are put forward to achieve the aforementioned research goal. Obtaining on a survey data from 202 manufacturing SMEs in Malaysia, the findings of the study confirmed that all hypotheses have a positive significant association. Theoretically and in practice, this study denotes rich addition to the vocabulary of business and management.
\end{abstract}

\section{Introduction}

Today, Small Medium Enterprises (SMEs) has become one of the key competitive sectors in emerging economies and has been said as constant environmental changes. In Malaysia, the SMEs' contribution to overall gross-domestic product (GDP) in 2015 was reported at $35.9 \%$ [1]. In gaining and sustaining the best company performance and competitive advantage, firms under SMEs need to be flexible, require moving creatively and quickly to adapt to changing conditions. Development on the most appropriate plan and taking into strategic decisions and actions in the new challenging environment are not an easy process in organizations. Improvisation is one of the business actions that entrepreneurial firms need to consider as it can diverge from strategic plans to instantaneously respond to opportunities when they emerge [2].

In the meantime, previous scholars have proved that improvisation may lead to business performance [3-6]. This appears that improvisation is significant to produce distinct business performance. However, the empirical evidence on this association is still scarce in management and business research. Henceforth, the aim of this study is to put forward three important objectives: to examine (1) the association between flexibility and improvisation, (2) the relationship between improvisation and performance; and (3) the mediating role of improvisation on the link between flexibility and SMEs performance.

We examine our objectives using survey data generated from SMEs manufacturing sector. This sector was chosen because SMEs manufacturing sector is considered as fast-moving setting where flexibility and improvisation are more likely to happen in their business practices. Further, according to Savita, Dominic and Ramayah (2016), Malaysia offers a costcompetitive avenue for investors to capitalize in manufacturing the technological and advanced products. This sector is the second largest contribution to overall GDP with $7.8 \%$ after SMEs service sector [1]. SMEs manufacturing companies are significant contributors to Malaysia's economic growth (MIDA, 2012), therefore there is a need to investigate this setting.

\section{The Hypotheses}

\section{Flexibility and Improvisation}

Flexibility in general means an ability to adapt or change. In organizational approach, flexibility is suggested to enable organizations to manage uncertain and 'fast-occurring' markets effectively and provide a capability to promptly generate and grasp upon creativities and opportunities [7]. Scholars stated that flexibility is one of the elements of improvisation. Improvisation is an action involved in real time situations in which it tangled a high degree of spontaneity and creativity in convergence of plan and implementation by individuals, groups, or the whole organization [8-9]. Improvisation is a conscious choice rather than something that occurs by chances $[5,10$ 11]. Organizational improvisation has been said to create value added to the organization [12]. Organizations need to understand how organizational flexibility can affect improvisation in the business. Flexibility is essentially considered as a basic 'infrastructure' that facilitate improvisation.

Organizational flexibility appears from the outcome of an interaction between the responsiveness of the

\footnotetext{
* Corresponding author: darwina@uum.edu.my
} 
organizational and managerial capabilities [13]. Managerial capabilities can be individuals or team of the firms. In organization, flexible individuals or team are believed to be able to explore in an extensive range of approaches to a problem without misleading their overall goal. This is unlike to less flexible individuals or team who are more obsessed with stability, direction, and precision and are more possible to suffer considerable stress and loss of control when threatened with changing environments. In some circumstances, flexible individuals or team within organizations could generate a greater flexible management systems and means of operating, strategizing and hence, decision making. The managerial flexibility will thus collectively would create the capacity of organizational flexibility. Thus, the hypothesis is as follows:

Hypothesis 1: Firms with high levels of flexibility exhibit greater levels of improvisation.

\section{Improvisation and Performance}

Improvisation is defined as an action taken in real time situations where it encompasses a high amount of spontaneity and creativity [4, 9]. Crossan (1997) posits that improvisation is the ability to plan and perform actions concurrently in organization where it may help providing superior performance and better innovative results. In early investigations, improvisation has typically relied on artistic metaphors such as jazz and theatre settings. While recent studies have proved that scholars much focus improvisation in organizational settings such as study on new product development [9, 14], export decision making [5-6] and firm performance [3-4] However,the study is still in infancy stage where only few studies available in the business management research.

In strategic management research, firm performance has long been agreed as an outcome in organizational phenomena. Prior researches have investigated several variables such as strategic planning and strategic making process [15-17], business-level, or corporate-level strategy [18-20], organizational structure and capabilities [19, 21], choice of environmental domains as well as organizational characteristics [4] on various performance. Such efforts have emphasized substantial consideration on the importance of improvisation at individual, group [22] and organizational performance. The study by Moorman and Miner (1998), Akgun and Lynn (2002) and Vera and Crossan (2005) disclose new product development as a result of team improvisation [9, 23]; Leybourne and Sadler-Smith (2006) study on the link between improvisation and the project performance [12]; Souchon and Hughes (2007) emphasis on export performance as an outcome of export improvisation [6]; and Hmieleski and Corbett (2008) reveal venture performance as an outcome of entrepreneurial improvisational behavior [25]. Only little studies have sought to deem and prove the relationship between organizational improvisation and firm performance (see Arshad and Hughes, 2009;
Arshad et al. 2015). Therefore, this study is hypothesized as below:

Hypothesis 2: The stronger the organizational improvisation, the better the firm performance of Malaysia manufacturing of SMEs.

The Relationship between Flexibility and Performance through Improvisation

Flexibility can be a mechanism of improvisation in which it endows the capacity of the organization to improvise. Greater organizational flexibility could help organizations to plan and execute simultaneously (improvisation) in a conscious manner. Whilst organizations seek to enhance their feasible performance in a rapid change environment by performing actions through improvisation [11]. This scenario is thus reflected that organizational improvisation can be the mediator that could enable organizations to proactively flexible to strengthen their performance. However this study is still empirically very limited proof, thus it is proposed in this study as below:

Hypothesis 3: through organizational improvisation as a mediator between flexibility and performance.

\section{Research method}

\subsection{Research setting and Sample Size}

The setting for this research is a stratified random of manufacturing SMEs which divided into three areas includes northern, southern, and central part of peninsular Malaysia. The target population of this research was the owner or entrepreneur or manager or top management of the manufacturing SMEs who directly involved with overall operation, routine and performance of the firm. Top managers were selected because they were the one who responsible for managing, making decisions as well as striving to reach competitive advantages. This study is limited to only examine the organizational flexibility, organizational improvisation and SMEs performance among Malaysian manufacturers.

According to Hair et al. (2010), the ratio of observations to independent variable should not fall below five $(5: 1)$ [25]. This study was used 24 items in exploratory factor analysis and structural equation modeling; therefore, it required a minimum sample size of 120 respondents.

\subsection{Data collection method}

This study was used on a nationwide-scale data collection involving the Malaysian Manufacturing SMEs as the central subject. Data was collected via a developed structured questionnaire. The questionnaire is a well-established method for social science research to obtain information about social characteristic of respondents, past and present behavior, standards of attitudes or behavior, and their reason for action with 
respect to the topic that being reviewed. The questionnaires were randomly distributed to SMEs based on directory of SME Corporation website. The questionnaire was delivered through e-mails or personally distributed by hand directly to the respondents. The respondents were given reasonable time to answer the questionnaires. The time period that the researchers took to deliver and collect all the questionnaires was two month through three major areas. The researchers were able to collect a total of 202 completed questionnaires to be analyzed in this study; in which it passes the minimum requirement of a sample size of 5:1 ratio.

\subsection{Measurement of variables and Data Analysis}

SMEs performance construct consists of flexibility are adapted from Jones, Rafferty, and Griffin (2006) with nine construct items. Whereas, organizational improvisation construct consists of seven items adapted from Vera and Crossan (2005); and five items adapted from the work of Ahmad, Wilson, and Kummerow (2011) was used for SMEs performance measures. The items for each construct and their scale of measurements are listed in Table I.For the data analysis, this study used the Partial Least Squares (PLS) approach using the SmartPLS3 to analyze the data. Bootstrapping method (500 resamples) was employed to determine the significance levels for loadings, weights, and path coefficients [26].

\section{Results}

\subsection{Demographic profile of respondents}

Results reveals that the majority of the manufacturing SMEs that participated in this study had been operating their business more than 20 years $(27.2 \%)$, followed by 5 to 10 years $(23.3 \%), 11$ to 15 years $(20.3 \%)$ and 16 to 20 years $(16.8 \%)$, while those operating under 5 years accounted for $12.4 \%$. The table also shows the majority $(74.3 \%)$ of the responding firms were small-sized firms ( 5 to 75 employees), and only $25.7 \%$ were mediumsized firms ( 75 to 200 employees).

\subsection{Measurement model}

There are two-staged processes involved in the analysis. Firstly, the assessment of the reliability and validity of the measurement model, and secondly, the assessment of the structural model. The research model of this study is depicted in Figure 1, which exhibits the loading for each item for this study.

To assess the measurement model, the researchers verified both reliability and validity. Reliability was measured through composite reliability and validity was assessed via convergent validity (as shown in Table 1) and discriminant validity (see Table 2). The analyses was done to confirm that the construct measurements are reliable and valid before evaluating the links in the structural model. Convergent validity can be proven if the loadings are larger than 0.5 , composite reliability (CR) greater than 0.7 and the average variance extracted (AVE) is greater than 0.5 [27].

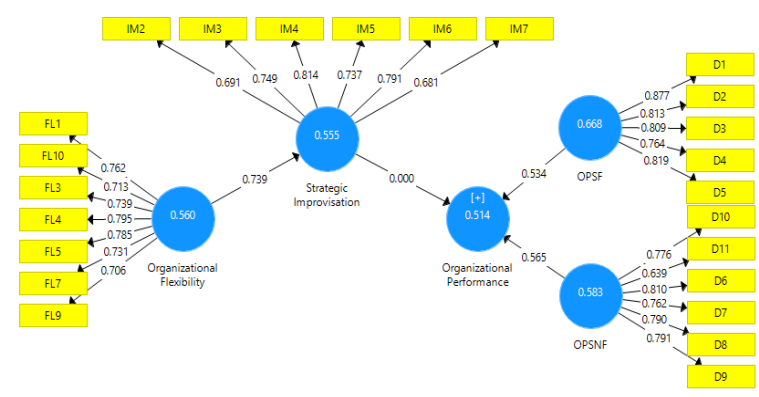

Fig. 1: Research model of the study

Table 1. Results of Measurement Model

\begin{tabular}{|c|c|c|c|c|c|c|}
\hline $\begin{array}{c}\text { First Order } \\
\text { Construct }\end{array}$ & $\begin{array}{l}\text { Second } \\
\text { Order } \\
\text { Construct }\end{array}$ & Scale Type & Item & $\begin{array}{l}\text { Loadings/ } \\
\text { weights }\end{array}$ & $\begin{array}{l}\text { AVE/ } \\
\text { VIF }\end{array}$ & $\begin{array}{l}\mathrm{CR} / \mathrm{t}- \\
\text { value }\end{array}$ \\
\hline Satisfaction & & Reflective & $\bar{D} 1$ & 0.877 & 0.688 & 0.909 \\
\hline Financial & & & D2 & 0.813 & & \\
\hline \multirow[t]{3}{*}{ Performance } & & & D3 & 0.809 & & \\
\hline & & & D4 & 0.764 & & \\
\hline & & & D5 & 0.819 & & \\
\hline Satisfaction & & Reflective & D6 & 0.810 & 0.583 & 0.893 \\
\hline Nonfinancial & & & D7 & 0.762 & & \\
\hline \multirow[t]{6}{*}{ Performance } & & & D8 & 0.790 & & \\
\hline & & & D9 & 0.791 & & \\
\hline & & & D10 & 0.776 & & \\
\hline & & & D11 & 0.639 & & \\
\hline & SMEs & Formative & OPSF & 0.534 & 1.780 & $26.599 * *$ \\
\hline & Performance & & $\begin{array}{c}\text { OPSN } \\
\mathrm{F}\end{array}$ & 0.565 & 2.163 & $26.400 * *$ \\
\hline Organizational & & Reflective & FL1 & 0.762 & 0.560 & 0.899 \\
\hline \multirow[t]{6}{*}{ Flexibility } & & & FL10 & 0.713 & & \\
\hline & & & FL3 & 0.739 & & \\
\hline & & & FL4 & 0.795 & & \\
\hline & & & FL5 & 0.785 & & \\
\hline & & & FL7 & 0.731 & & \\
\hline & & & FL9 & 0.706 & & \\
\hline Organizational & & Reflective & IM2 & 0.691 & 0.555 & 0.882 \\
\hline \multirow[t]{5}{*}{ Improvisation } & & & IM3 & 0.749 & & \\
\hline & & & IM4 & 0.814 & & \\
\hline & & & IM5 & 0.737 & & \\
\hline & & & IM6 & 0.791 & & \\
\hline & & & IM7 & 0.681 & & \\
\hline $\begin{array}{c}\text { First Order } \\
\text { Construct }\end{array}$ & $\begin{array}{c}\text { Second } \\
\text { Order } \\
\text { Construct } \\
\end{array}$ & $\begin{array}{l}\text { Scale } \\
\text { Type }\end{array}$ & Item & $\begin{array}{c}\text { Loadings } \\
\text { weights }\end{array}$ & $\begin{array}{c}\text { AVE/ } \\
\text { VIF }\end{array}$ & $\begin{array}{l}\mathrm{CR} / \mathrm{t}- \\
\text { value }\end{array}$ \\
\hline Satisfaction & & Reflective & D1 & 0.877 & 0.688 & 0.909 \\
\hline Financial & & & D2 & 0.813 & & \\
\hline \multirow{3}{*}{ Performance } & & & D3 & 0.809 & & \\
\hline & & & D4 & 0.764 & & \\
\hline & & & D5 & 0.819 & & \\
\hline Satisfaction & & Reflective & D6 & 0.810 & 0.583 & 0.893 \\
\hline Nonfinancial & & & D7 & 0.762 & & \\
\hline \multirow[t]{6}{*}{ Performance } & & & D8 & 0.790 & & \\
\hline & & & D9 & 0.791 & & \\
\hline & & & D10 & 0.776 & & \\
\hline & & & D11 & 0.639 & & \\
\hline & SMEs & Formative & OPSF & 0.534 & 1.780 & $26.599 * *$ \\
\hline & Performance & & $\begin{array}{c}\text { OPSN } \\
\text { F }\end{array}$ & 0.565 & 2.163 & $26.400^{* *}$ \\
\hline Organizational & & Reflective & FL1 & 0.762 & 0.560 & 0.899 \\
\hline \multirow[t]{6}{*}{ Flexibility } & & & FL10 & 0.713 & & \\
\hline & & & FL3 & 0.739 & & \\
\hline & & & FL4 & 0.795 & & \\
\hline & & & FL5 & 0.785 & & \\
\hline & & & FL7 & 0.731 & & \\
\hline & & & FL9 & 0.706 & & \\
\hline Organizational & & Reflective & IM2 & 0.691 & 0.555 & 0.882 \\
\hline \multirow[t]{2}{*}{ Improvisation } & & & IM3 & 0.749 & & \\
\hline & & & IM4 & 0.814 & & \\
\hline
\end{tabular}




$\begin{array}{ll}\text { IM5 } & 0.737 \\ \text { IM6 } & 0.791 \\ \text { IM7 } & 0.681\end{array}$

Note: $\mathrm{AVE}=$ (summation of the square of the factor loadings $) /$ (summation of the square of the factor loadings $)+($ summation of the error variances $)\} ; \mathrm{CR}=$ (square of the summation of the factor loadings)/ \{(summation of the square of the factor loadings) + (summation of the square of the error variances) $\}$

From the result of the study, the loadings range from 0.639 to 0.877 in which showed more than half of the variance in the observed variable was explained by the constructs. The CR values explained the degree to which the construct items represent the latent, which were in the range of 0.882 and 0.909. The AVE measures "the degree to which a latent construct explains the variance of its items" (Hair et al., 2014, p.114), which was in the range of 0.555 and 0.688 . In this study, SMEs performance was modeled as secondorder formative constructs. Three steps were involved in measuring formative measures: (i) test for weight significant; (ii) test for multi-collinearity; and (iii) test of the correlation of the indicators with the latent construct.

This study found that the statistical significance of weights implies the relative importance of indicators in forming a latent construct. The analysis also demonstrated that all items had VIF of less than 5, indicating no threat of multi-collinearity between the different indicators [28]. Finally, the correlation of the indicators with the latent construct was tested to find out their absolute contribution. Result revealed that all items had a significant weight and were correlated to the latent constructs. Consequently, all items in the formative construct were retained for further analysis. From Table 1, the results prove that all the three construct, flexibility, performance and improvisation are valid measures of their respective constructs based on their parameter estimates and statistical significance [29].

Discriminant validity (see Table 2) was tested using the Fornell and Lacker (1981) criterion which proposes that more variance is shared by a latent construct with its own indicators than with other latent construct in the structural model [30]. Table 2 illustrates that all the square root of the AVE values was larger than other correlation values among the latent variables, indicating that several constructs used in the model belong to distinct entities. In essence, the measurement model displayed good discriminant validity among constructs.

Table 2: Fornell-Lurker Criterion

\begin{tabular}{|c|c|c|c|c|}
\hline & OPSF & OPSNF & $\begin{array}{l}\text { Organizational } \\
\text { Flexibility }\end{array}$ & $\begin{array}{c}\text { Organizational } \\
\text { Improvisatio } \\
\mathrm{n}\end{array}$ \\
\hline OPSF & 0.817 & & & \\
\hline OPSNF & 0.656 & 0.763 & & \\
\hline $\begin{array}{l}\text { Organizational } \\
\text { Flexibility } \\
\text { Organizational }\end{array}$ & 0.506 & 0.669 & 0.748 & 0.745 \\
\hline Improvisation & 0.457 & 0.59 & 0.739 & \\
\hline
\end{tabular}

Note: Diagonals (in bold) represent the square root of AVE while the other entries represent the correlation

\subsection{Structural model}

As this study calls for the measurement of both reflective and formative in the same model, the twostage approach were used to test the hypothesis (Hair et al., 2014). The results are presented in Figure landTable 3 . The $\mathrm{R}^{2}$ values of 0.546 and 0.357 which propose that flexibility and improvisation contributed 54.6 and 35.7 percent of the variance in the respective dependent variables. As shown in Table III, all hypotheses were fully supported which was confirmed a positive and significant association between flexibility and improvisation $(\beta=0.739, \mathrm{t}=17.267, \mathrm{p}<$ $0.01)$ and organizational improvisation and performance $(\beta=0.597, \mathrm{t}=12.370, \mathrm{p}<0.01)$. The bootstrapping analysis also showed that the indirect effect ( $\beta=0.441$ ) was significant with $\mathrm{t}$-value of 8.204. Also, as indicated by Preacher and Hayes (2008), the indirect effect $95 \%$ Boot CI: $[\mathrm{LL}=0.325, \mathrm{UL}=0.535]$, did not straddle a 0 in between, indicating there is mediation. Thus, the result revealed that the mediation effect of organizational improvisation on the relationship between organizational flexibility and SMEs performance was statistically significant $(\beta=$ $0.441, \mathrm{t}=8.204, \mathrm{p}<0.01)$.

Table 3: Path Coefficients and Hypotheses Testing

\begin{tabular}{|c|c|c|c|c|c|c|c|}
\hline \multirow[b]{2}{*}{ H } & \multirow[b]{2}{*}{ Relationship } & \multirow[b]{2}{*}{ Beta } & \multirow[b]{2}{*}{ SE } & \multicolumn{4}{|c|}{$\begin{array}{c}\text { Bootstrapped } \\
\text { Confidence } \\
\text { Interval } \\
\text { (Boot CI) }\end{array}$} \\
\hline & & & & t-value & $\begin{array}{c}95 \% \\
\text { LL } \\
\end{array}$ & $\begin{array}{c}95 \% \\
\text { UL }\end{array}$ & Decision \\
\hline H1 & $\begin{array}{l}\text { Flexibility -> } \\
\text { Improvisation }\end{array}$ & 0.739 & 0.043 & $\begin{array}{c}17.267 * \\
* \\
\end{array}$ & - & - & Supported \\
\hline $\mathrm{H} 2$ & $\begin{array}{l}\text { Improvisation - } \\
\text { >SMEs } \\
\text { Performance }\end{array}$ & 0.597 & 0.048 & $\begin{array}{c}12.370 * \\
*\end{array}$ & - & - & Supported \\
\hline $\mathrm{H} 3$ & $\begin{array}{l}\text { Flexibility -> } \\
\text { Improvisation - } \\
\text { > SMEs } \\
\text { Performance }\end{array}$ & 0.441 & 0.054 & $8.204 * *$ & 0.325 & 0.535 & Supported \\
\hline
\end{tabular}

Note: ${ }^{*} \mathrm{P}<0.05(1.645), * * \mathrm{P}<0.01(2.33)$

\section{Implications and Contributions}

Our primary contributions of this paper is to provide theoretical and practical research gaps. This study explores the understanding on the significant element of improvisation which are based upon organizational flexibility, as well as to provide empirical evidence on whether the flexibility could exist an effect on performance through organizational improvisation. Improvisation in the business is believed that it could generate a good outcome, which is to lead to superior performance. The finding of this study implies that top managers or decision-makers of companies need to consider implementing improvisational practice in their organizations in order to gain and sustain superior firm performance. In addition, flexibility is assumed as a desired outcome of improvisation as it is also apparent 
here that flexibility is a necessary condition for improvisation to occur. The finding thus indicates that organizational flexibility provides the ability to improvise organizational activities by committing resources to new courses of actions in response to those changes and therefore affect better performance return. This organizational flexibility enables organizations to recognize and improvise promptly to respond to various demands and opportunities existing in a dynamic and uncertain competitive environment in gaining and sustaining best firm performance.

The study also emphasized several essential areas that some parties need to be concerned. Concerning on the improvisational activities that add on the business practice in organization, firms are believed to be more competence to survive in its business. In the condition of limited resources and with fast and rapid environmental change, firms need to be decided and acted strategically. Therefore, element of improvisation is significant as it could gain and sustain the growth and survival of the firms, specifically in SMEs setting.

\section{Conclusion}

SMEs should be flexible to enable a creative and spontaneous move to respond on the frequent changing environment. Taking decisions out of the traditional planning process by creating improvisational practice is still scarce in the organizations' management system. The pursuit investigation on the relationships between the aforementioned three hypotheses is reasonable given that improvisation normally involves creative and spontaneous decisions and actions which enabling the alteration of pre-planned activities or semi-structured work processes; organizational flexibility can be the element that affect improvisation; while firm performance is the firms' business success.

\section{References}

1. SME Corporation Malaysia, SME Statistic, http://www.smecorp.gov.my/index.php/en/policie s/2015-12-21-09-09-49/sme-statistics

2. Hughes, P., Hodgkinson, I., Hughes, M., \& Arshad, D. Explaining the entrepreneurial orientation-performance relationship in emerging economies: The intermediate roles of absorptive capacity and improvisation. Asia Pacific Journal of Management, in press. (2017).

3. Arshad, D. \& Hughes, P. (2009). Examining organizational improvisation: the role of strategic reasoning and managerial factors International. Journal of Social, Behavioral, Educational, Economic and Management Engineering, 3(6), 948-954.

4. Arshad, D., Julienti, L., Ahmad, H. \&Hafizi, S. (2015). Unraveling the Link between Environmental Factors and Organizational Improvisation. In E-Proceeding of the International Conference on Social Science Research, ICSSR 2015, 647-655.
5. Nemkova, E., Souchon, A. L., Hughes, P., \&Micevski, M., Does Improvisation Help or Hinder Planning in Determining Export Success? Decision Theory Applied to Exporting. Journal of International Marketing, 23, 41-65.

6. Souchon, A.L. and Hughes, P. (2007). Improvising export decisions: A contingency theory perspective. International and Cross-cultural Marketing, Track 8.

7. Dunford, R. (2013). "Flexibility" as the rationale for organizational change: a discourse perspective. Journal of Organizational Change Management, 26, 83-97.

8. Moorman, C., \& Miner, A. S. (1998). The convergence of planning and execution: Improvisation in new product development. Journal of Marketing, 61, 1-20.

9. Vera, D. \& Crossan, M. (2005). Improvisation and Innovative Performance in Teams. Organization

10. Arshad, D. (2011). Understanding organisational improvisation: foundations and performance implications. PhD Thesis, Loughborough University.

11. Arshad, D., Razalli, R., Julienti, L., Ahmad, H., \& Mahmood, R. (2015). Exploring the Incidence of Strategic Improvisation: Evidence from Malaysian Government Link Corporations. Asian Social Science, 11, 105-112.

12. Leybourne, S. (2006). Improvisation within the Project Management of Change: Some Observations from UK Financial Services. Journal of Change Management, 6, 365-381.

13. Michielsens, E., Bingham, C., \& Clarke, L., Managing diversity through flexible work arrangements: management perspectives. Employee Relations, 36(1), 49-69.

14. Kyriakopolous, K. (2011). Improvisation in product innovation: the contingent role of market information sources and memory types. Organizational Studies, 32(8), 1051-1078.

15. Rogers, P.R., Miller, A., and Judge, W.Q. (1999). Using information-processing theory to understand planning/performance relationships in the context of strategy. Strategic Management Journal, 20(6), 567-577.

16. Brews, P.J. and Hunt, M.R. (1999). Learning to plan and planning to learn: Resolving the planning school/learning school debate. Strategic Management Journal, 20(10), 889-913.

17. Slotegraaf, R.J. and Dickson, P.R. (2004). The paradox of a marketing planning capability. Journal of the Academy of Marketing Science, 32(4), 71-385.

18. Porter, M. E. (1980). Competitive Strategy: Techniques for Analyzing Industries and Competitors. New York, NY: The Free Press, 1980.

19. Miller, D. (1998). Relating Porter business strategies to environment and structure: Analysis and performance implications. The Academy of Management Journal, 31(2), 280-308. 
20. Liao, Y.S. (2005). Business strategy and performance: The role of human resource management control. Personal Review, 34(3), 294-305.

21. Burns, T. and Stalker, G.M. (1961). The management of innovation. Oxford: Oxford University Press.

22. Kamoche, K., Cunha, M., \& Cunha, J. (2002). Organizational Improvisation. London: Routledge.

23. Akgün, A.E., Lynn, G.S., Byrne, J.C. (2006). Antecedents and consequences of unlearning in new product development teams. Journal of Product Innovation Management, 23, 73-88.

24. Hmieleski, K.M. and Corbett, A.C. (2008). The contrasting interaction effects of improvisational behaviour with entrepreneurial self-efficacy on new venture performance and entrepreneur work satisfaction. Journal of Business Venturing, 23(4), 482-496.

25. Hair, J. F., Sarstedt, M., Hopkins, L., \& Kuppelwieser, V. G. (2014). Partial least squares structural equation modeling (PLS-SEM): An emerging tool in business research. European Business Review, 26(2), 106-121.
26. Chin, W. W. (2010). How to write up and report PLS analyses. In V. E. Vinzi, W. W. Chin, J. Henseler\& H. Wang (Eds.), Handbook of Partial Least Squares: Concepts, Methods and Applications 2(28), 655-690. New York: Springer Heidelberg Dordrecht.

27. Hair, J. F., Hult, G. T. M., Ringle, C. M., \&Sarstedt, M. (2014). A primer on partial least squares structural equation modelling (PLSSEM): SAGE Publications, Inc.

28. Luk, C. L., Yau, O. H. M., Sin, L. Y. M., Tse, A. C. B., Chow, R. P. M., \& Lee, J. S. Y. (2008). The effects of social capital and organizational innovativeness in different institutional contexts. Journal of International Business Studies, 39(4), 589-612.

29. Chow, W. S., \& Chan, L. S. (2008). Social network, social trust and shared goals in organizational knowledge sharing. Information \& Management, 45(7), 458-465.

30. Fornell, C., \& Larcker, D. F. (1981). Evaluating structural equation models with unobservable variables and measurement error. Journal of Marketing Research (JMR), 18(1), 39-50. 